\title{
Evaluation of Morphine Effect on Tumor Growth in Mice
}

Santana Huang AP ${ }^{1}$, Rey Moura EC ${ }^{2}$, Cunha Leal PD ${ }^{2}$, Bogéa Serra ICP², Fernandes do Nascimento RR $^{2}$ and Sakata RK ${ }^{\star}$

${ }^{1}$ Universidade Federal de São Paulo, Brazil

${ }^{2}$ Universidade Federal do Maranhão, Brazil

*Corresponding author: Rioko Kimiko Sakata, Universidade Federal do Maranhão, Rua Três de Maio 61/51, Vila Clementino, São Paulo, CEP 04044-020, Brazil, Tel: 055115576 4848- voip 17006; E-mail: rsakata@unifesp.br

Received date: April 27, 2018; Accepted date: June 01, 2018; Published date: June 05, 2018

Copyright: ( 2018 Sakata RK, et al. This is an open-access article distributed under the terms of the Creative Commons Attribution License, which permits unrestricted use, distribution, and reproduction in any medium, provided the original author and source are credited.

\section{Abstract}

Background and objectives: The role of opioids on tumor growth is widely discussed. The aim of this study was to analyze whether morphine has a direct influence on tumor growth.

Methods: Twenty mice received intraperitoneal inoculation of Ehrlich tumor cells and were divided into two groups. Morphine group received $10 \mathrm{mg} / \mathrm{kg}$, and the control group received $0.9 \%$ saline solution, once daily for 7 days, by gavage of $10 \mathrm{ml} / \mathrm{kg}$. On the tenth day, 5 animals were sacrificed, and 5 were evaluated for survival in each group. The following were evaluated: survival; abdominal circumference; ascites volume; weight; tumor cells in ascites; lymphocytes in the spleen, inguinal and mesenteric lymph nodes and bone marrow; cytokines in ascites, serum, lymph nodes and spleen; nitric oxide (NO) in ascites and spleen; nitrite in ascites; arginase in ascites; superoxide dismutase (SOD) in ascites; and immunophenotyping of the spleen.

Results: The number of cells in the bone marrow was higher after morphine treatment; SOD was higher in ascites after morphine, and the NO level of the spleen stimulated with lipopolysaccharide (LPS) was lower after morphine treatment. There were no differences in the other parameters.

Conclusion: The results of this study show that morphine causes some changes that facilitate tumor growth in mice as higher NO in ascites and, although there were no significant differences, weight, ascites volume and the abdominal circumference was higher after morphine treatment.

Keywords: Cancer; Morphine; Tumor growth; Immunophenotyping; Cytokines

\section{Introduction}

Pain is one of the most common symptoms of cancer and up to $90 \%$ of advanced stage cancer patients will present with moderate to severe pain [1]. Guidelines for the management of cancer pain were developed by the World Health Organization (WHO) are based on an analgesic ladder [2].

Opioids are the drugs of choice for the management of severe cancer pain $[2,3]$. In addition, the postoperative analgesia for cancer surgery patients most often includes opioids. Morphine and other opioids are used in escalating doses to control severe pain in cancer patients.

However, the role of opioids in tumor growth has been discussed. Some studies show that morphine could stimulate tumor growth [4-7]. However, there are reports that these drugs may alter cancer recurrence or metastasis. Opioids could affect the function of $\mathrm{T}$ lymphocytes [8], and stimulate the release of inflammatory cytokines [7].

Despite this, other study shows that there is insufficient evidence to confirm tumor growth with opioids [9]. The literature, however, presents some discrepancies, with reports suggesting that opioids may either promote or prevent tumor growth.
This issue is so controversial that some authors demonstrated that morphine had an inhibitory effect on tumor growth [10-12]. Some studies indicate that morphine may prevent cancer progression [12-14]. Other opioids (tramadol and codeine) also had inhibitory effect for cancer $[14,15]$.

It is of very important to determine whether morphine is harmful to cancer patients. There have been inconsistent reports on whether opioids promote or inhibit cancer growth. The effect of opioids for cancer populations are inconclusive and definitive recommendations cannot be made.

\section{The Aim of the Study}

The aim of this study is to evaluate whether morphine has an influence on tumor growth.

\section{Materials and Methods}

Twenty female Swiss mice, 8 weeks of age and weighing on average $28 \mathrm{~g}$, were used ( $\mathrm{n}=10$ /group). The animals were kept at $26 \pm 2{ }^{\circ} \mathrm{C}, 44-$ $56 \%$ relative humidity, under $12 \mathrm{~h}$ light-dark cycles and had free access to sterile food and acidified water. All procedures have been assessed and approved by the Committee of Ethics in Research (Protocol: 23115.002502/2015-78).

Ehrlich tumor is an aggressive breast carcinoma-associated with short survival in mice. The Ehrlich tumor was maintained in the ascites 
Citation: Santana Huang AP, Rey Moura EC, Cunha Leal PD, Bogéa Serra ICP, Fernandes do Nascimento FR, et al. (2018) Evaluation of Morphine Effect on Tumor Growth in Mice. Clin Exp Pharmacol 8: 249. doi:10.4172/2161-1459.1000249

Page 2 of 5

form by passages in Swiss mice, by weekly intraperitoneal transplantation of $2 \times 10^{6}$ tumor cells. The ascites fluid was removed, and tumor cell counts were done in a Neubauer hemocytometer. The cells were found to be more than $99 \%$ viable by the Trypan blue dye $(0.2 \%)$ exclusion method.

Each animal received an intraperitoneal inoculation of $2 \times 10^{6}$ tumor cells. The mice were then separated into two groups to receive $10 \mathrm{mg} / \mathrm{kg}$ of morphine (morphine group) or normal saline solution in the control group (C) from days 2 to 8 . Morphine or normal saline were administered by gavage once a day. Then, the mice were observed for survival analysis. The remaining animals were sacrificed on day 10 for evaluation of tumor development and immunological parameters.

There were evaluated: survival; abdominal circumference; ascites volume; weight; tumor cells in ascites; leucocytes in the spleen, lymph nodes and bone marrow; cytokines (monocyte chemotactic protein-1 (MCP1), tumor necrosis factor- $\alpha$ (TNFa), interferon- $\gamma$ (IFN $\gamma$ ), interleukin (IL) 6, 10 and 17) in ascites, serum, lymph nodes and spleen; nitric oxide (NO) in ascites and spleen; nitrite in ascites; arginase in ascites; superoxide dismutase (SOD) in ascites; and immunophenotyping of the spleen.

The percent of the increase in the lifespan (ILS) was calculated considering the mean survival time (MST) of each group according to equation (Gupta et al.,):

$I L S(\%)=\frac{(\text { MST of the treated group }- \text { MST of the control group })}{\text { MST of the control group }} \times 100$

\section{Statistical analysis}

For statistical analysis, it was used the software Graph Pad Prism $5.0^{\circ}$. The tests used were: log-rank to compare survival; Student-t to compare all other parameters between morphine and saline group. It was considered statistically significant $\mathrm{p} \leq 0.05$.

\section{Results and Discussion}

There was no difference in the survival of the animals (median was 16 days for both groups; $p=0.887, \log$-rank test). There were no differences in weight; abdominal circumference; ascites volume; tumor cells number in ascites, spleen, and mesenteric lymph node; the number of cells in the bone marrow was higher after morphine (Table 1). There were no differences in cytokine concentrations (Table 2). There were no differences in arginase, nitrite and SOD levels in ascites or the spleen (isolated or stimulated with tumor cells), while NO was higher in ascites in the morphine group, with no difference in the spleen (Table 3). There was no difference in a number of cells in the spleen (Table 4).

\begin{tabular}{|l|l|l|l|}
\hline & Morphine & Control & p \\
\hline Weight $(\mathrm{g}) \mathrm{a}$ & $9.6 \pm 1.8$ & $6.8 \pm 1.3$ & 0.558 \\
\hline Ascites $\mathrm{V}(\mathrm{ml})$ & $10.3 \pm 0.7$ & $9.4 \pm 1.3$ & 0.526 \\
\hline $\begin{array}{l}\text { Circumference }(\mathrm{cm}) \\
\text { Tumoral cel }\end{array}$ & $10.3 \pm 0.6$ & $9.5 \pm 0.5$ & 0.310 \\
\hline Ascites tumoral cel $\left(\mathrm{x} 10^{8} / \mathrm{ml}\right)$ & $433.8 \pm 22.2$ & $604.2 \pm 95.4$ & 0.120 \\
\hline Spleen cel $\left(10^{7} / \mathrm{ml}\right)$ & $1.4 \pm 0.2$ & $1.5 \pm 0.3$ & 0.623 \\
\hline
\end{tabular}

\begin{tabular}{|l|l|l|l|}
\hline $\mathrm{ML}$ cel $\left(10^{7} / \mathrm{ml}\right)$ & $2.4 \pm 0.4$ & $2.6 \pm 0.4$ & 0.810 \\
\hline BM cel $\left(10^{7} / \mathrm{ml}\right)$ & $0.8 \pm 0.1$ & $0.5 \pm 0.1$ & 0.049 \\
\hline
\end{tabular}

Table 1: Weight, the volume of ascites, abdominal circumference, ascites tumor cells and number of cells in spleen, mesenteric lymph node, and bone marrow (mean $\pm \mathrm{SE}$ ). $\mathrm{V}=$ volume; $\mathrm{Cel}=$ cells; $\mathrm{ML}=$ mesenteric lymph nodes; $\mathrm{BM}=$ bone marrow; t-test; SE: standard error.

The results of this study show that morphine causes some alterations associated with tumor growth. The action of morphine on tumor growth was studied because it is the most used analgesic for relieving the severe cancer pain. There is some evidence supporting a protumorigenic role for opioids [16]. This evidence raised questions about the role of opioids in the control of cancer pain, but the studies are conflicting, and not clarified the effect of these drugs [9]. The authors of one study reported that morphine does not influence tumor development but promotes progression [7].

Tumor growth depends on the balance between the aggressiveness of the tumor and the defence of the organism [16]. Some studies have shown that opioids affect tumor cell-destroying $\mathrm{T}$ lymphocytes, antibody production and the functions of phagocytic cells and cytokines [16,17].

Pain also causes reduced natural killer (NK) cells and immunity, while good pain control results in reduced metastases [18].

\begin{tabular}{|l|l|l|l|}
\hline Ascites & Morphine & Control & P \\
\hline MCP-1 & $4301 \pm 802.9$ & $3616 \pm 673$ & 0.531 \\
\hline TNF- $\alpha$ & $32.6 \pm 3.8$ & $43.8 \pm 7.6$ & 0.223 \\
\hline IFN-Y & $13.9 \pm 3.5$ & $19.9 \pm 8.2$ & 0.517 \\
\hline IL-6 & $67.0 \pm 12.0$ & $54.7 \pm 12.7$ & 0.498 \\
\hline IL-10 & $9.2 \pm 1.3$ & $9.5 \pm 3.3$ & 0.941 \\
\hline IL-17 & $0.0 \pm 0.0$ & $0.4 \pm 0.3$ & Not calculated \\
\hline Serum & & & \\
\hline MCP-1 & $587.8 \pm 180.2$ & $326.1 \pm 92.6$ & 0.232 \\
\hline TNF-Y & $35.2 \pm 4.3$ & $27.1 \pm 6.9$ & 0.348 \\
\hline IFN-g & $2.6 \pm 0.3$ & $4.0 \pm 0.9$ & 0.194 \\
\hline IL-6 & $5.9 \pm 0.7$ & $5.0 \pm 1.5$ & 0.613 \\
\hline IL-10 & $0.7 \pm 0.6$ & $1.8 \pm 1.4$ & 0.477 \\
\hline IL-17 & $0.2 \pm 0.2$ & $0.5 \pm 0.5$ & 0.526 \\
\hline Spleen & $0.0 \pm 0.0$ & $389.3 \pm 141.6$ & 0.101 \\
\hline MCP-1 & $1.7 \pm 0.5$ & $0.9 \pm 5.7$ & 0.714 \\
\hline TNF- $\alpha$ & $0.0 \pm 0.0$ & $0.0 \pm 0.0$ & Not calculated \\
\hline IFN-Y & $0.0 \pm 0.0$ & & 0.434 \\
\hline IL-6 & & Not calculated \\
\hline IL-10 & & & \\
\hline IL-17 & & & \\
\hline
\end{tabular}


Citation: Santana Huang AP, Rey Moura EC, Cunha Leal PD, Bogéa Serra ICP, Fernandes do Nascimento FR, et al. (2018) Evaluation of Morphine Effect on Tumor Growth in Mice. Clin Exp Pharmacol 8: 249. doi:10.4172/2161-1459.1000249

Page 3 of 5

\begin{tabular}{|l|l|l|l|}
\hline Lymph nodes & & & \\
\hline MCP-1 & $222.4 \pm 83.2$ & $172.8 \pm 74.2$ & 0.680 \\
\hline TNF- $\alpha$ & $0.0 \pm 0.0$ & $0.0 \pm 0.0$ & Not calculated \\
\hline IFN-Y & $0.0 \pm 0.0$ & $0.0 \pm 0.0$ & Not calculated \\
\hline IL-6 & $1.3 \pm 0.8$ & $0.7 \pm 0.2$ & 0.440 \\
\hline IL-10 & $0.0 \pm 0.0$ & $0.0 \pm 0.0$ & Not calculated \\
\hline IL-17 & $0.0 \pm 0.0$ & $0.0 \pm 0.0$ & Not calculated \\
\hline
\end{tabular}

Table 2: Cytokines concentrations (pg/mL; mean \pm SE). IL: interleukin; IFN- $\gamma$ : Interferon-gamma; TNF- $\alpha$ : Tumor necrosis factor-alpha; MCP: monocytes quimiotatic protein; SE: standard error; Student-t test; ${ }^{*}$ : significant

In this study, was $10 \mathrm{mg} / \mathrm{kg}$ of morphine, higher than that usually used in humans for cancer pain. Doses used in the animal literature differ widely but range from $5-20 \mathrm{mg} / \mathrm{kg}$ [19]. In this study, an intermediate dose was chosen.

To study tumor growth by morphine in this study, several direct measurements (weight gain, abdominal circumference, ascites volume and a number of tumor cells), substances associated with tumor growth (cytokines, NO, arginase and SOD) and immunosuppression (numbers of helper and cytotoxic T lymphocytes in the spleen) were evaluated.

Survival was assessed to determine whether any reductions observed were due to adverse effects on tumor growth. Although there were no significant differences, weight, ascites volume and abdominal circumference were higher after morphine treatment, which may indicate greater tumor growth.

\begin{tabular}{|l|l|l|l|}
\hline Ascites arginase $(\mathrm{und} / \mathrm{L})$ & $\begin{array}{l}44.5 \quad \pm \\
3.6\end{array}$ & $51.4 \pm 7.1$ & 0.220 \\
\hline Ascites nitrite $(\mu \mathrm{M})$ & $5.6 \pm 0.2$ & $5.6 \pm 0.2$ & 0.508 \\
\hline Ascites SOD $(\%)$ & $\begin{array}{l}89.3 \quad \pm \\
2.6\end{array}$ & $87.5 \pm 0.5$ & 0.530 \\
\hline Ascites NO $(\mu \mathrm{M})$ & $\begin{array}{l}21.2 \quad \pm \\
0.9\end{array}$ & $14.1 \pm 2.0$ & 0.014 \\
\hline Spleen NO $(\mu \mathrm{M})$ & $0.1 \pm 0.0$ & $0.07 \pm 0.0$ & 0.270 \\
\hline $\begin{array}{l}\text { Spleen NO stimulated with tumor cells } \\
(\mu \mathrm{M})\end{array}$ & $2.1 \pm 0.5$ & $3.1 \pm 0.9$ & 0.300 \\
\hline Spleen NO stimulated with LPS $(\mu \mathrm{M})$ & $2.8 \pm 0.5$ & $4.3 \pm 2.8$ & 0.600 \\
\hline
\end{tabular}

Table 3: Dosage of NO, nitrite, SOD, and arginase (mean \pm SE). SOD: superoxide dismutase; NO: nitric oxide; SE: standard error; Student-t test; ${ }^{*}$ : significant

Analyses of as many fluids and organs as possible were performed to provide more information on the effect of morphine. Local inflammatory reactions can be verified in the ascites, and systemic reactions can be observed in the blood. A drug's toxicity can be observed in the mesenteric lymph node, while the greatest production of defence cells occurs in the spleen.

Cytokine levels were evaluated at sites of easy collection and with an increased immune response due to tumor growth. Several cytokines stimulate tumor growth, including IL-6, IL-17, MCP-1 and TNF [20-23].

IFN- $\alpha$ and IL-10 are anti-tumour cytokines. MCP-1 and IL-6 levels were higher after morphine treatment, although the differences were not significant [24-27].

Nitrite, SOD, and arginase were measured in ascites, the area of greatest inflammation in the tumor type studied.

\begin{tabular}{|l|l|l|l|}
\hline & Morphine & Control & P \\
\hline Cells number $\left(\times 10^{5}\right)$ & & & 0.880 \\
\hline Total T lymphocytes $(\mathrm{CD} 3+)$ & $2.72 \pm 0.31$ & $2.79 \pm 0.28$ & 0.445 \\
\hline T helper lymphocytes (CD3+CD4+) & $1.0 \pm 0.18$ & $1.2 \pm 0.19$ & 0.157 \\
\hline T cytotoxic lymphocytes (CD3+CD8+) & $0.25 \pm 0.11$ & $0.46 \pm 0.06$ & 0.280 \\
\hline Activated T cells $\left(\times 10^{5}\right)$ & & & 0.070 \\
\hline Activated T helper (CD3+CD4+CD28+) & $0.25 \pm 0.02$ & $0.08 \pm 0.01$ & \\
\hline Activated T cytotoxic (CD3+CD8+CD28+) & $0.11 \pm 0.01$ & \\
\hline
\end{tabular}

Table 4: Absolute frequency of splenic T helper and T cytotoxic lymphocytes (mean \pm SE). SE: standard error; Student-t test; ${ }^{*}$ significant

NO can have as much of an effect on tumor dissemination as on tumoricidal activity. At lower concentrations $(<100 \mu \mathrm{M})$, NO causes tumor progression; at higher concentrations $(>100 \mu \mathrm{M})$, it induces apoptosis of tumor cells [28]. In this study, only ascites had higher NO levels with morphine treatment, but the concentrations in both locations were $<100 \mu \mathrm{M}$, considered to be pro-tumoral. $\mathrm{NO}$ is degraded to form nitrite, which indirectly measures NO production.
In this study, arginase levels were lower with morphine treatment, although not significant. Arginase has a tumour-suppressive effect, but increased arginase activity causes a decrease in L-arginine, a substrate for the production of NO [29], with tumor growth. SOD eliminates free radicals and protects cells from injury [30].

Immunophenotyping was performed to evaluate lymphocytes in relation to tumor aggression. CD4+ and CD8+ T lymphocytes destroy tumor cells [31]. In this study, the spleen was chosen to verify 
alterations in defence cells because it contains higher concentrations of these cells.

\section{Conclusion}

The results of this study show that morphine causes some changes that facilitate tumor growth in mice as higher $\mathrm{NO}$ in ascites and, although there were no significant differences, weight, ascites volume and abdominal circumference was higher after morphine treatment, which may indicate greater tumor growth. However, more studies are needed to demonstrate the existence of a significant effect of morphine on tumor progression. It is still not possible to conclude that the use of morphine for the treatment of pain in patients with cancer is inadequate.

\section{Limitations}

There may be a difference between tumor types in morphineinduced growth induction. The results obtained in animals cannot be fully extrapolated to humans. In human studies, it is difficult to disconnect the possibility that exposure to high doses of opioid causes tumor progression from the possibility that the requirement for opioids is greater because tumor progression increases pain. The opioid dose may be important for tumor growth.

\section{Acknowledgement}

Coordination of Improvement of Higher Education Personnel (CAPES)

\section{Funding statement}

Fundação de Amparo à Pesquisa do Estado do Maranhão (grant $\mathrm{n}^{\circ}$ 01354/16 to Flávia Raquel Fernandes do Nascimento, grant $\mathrm{n}^{\circ}$ 00572/14 to Izabel Cristina Portela Bogéa Serra, http:// www.fapema.br).

\section{Conflict of Interest}

None

\section{References}

1. Esin E, Yalcin S (2014) Neuropathic cancer pain: What we are dealing with? How to manage it? Onco Targets Ther 7: 599-618.

2. Ripamonti C, Santini D, Maranzano E, Berti M, Rolia F (2012) Management of cancer pain: ESMO Clinical Practice Guidelines. Ann Oncol 23: 139-154.

3. Boland JW, McWilliams K, Ahmedzai SH, Pockley AG (2014) Effects of opioids on immunologic parameters that are relevant to anti-tumour immune potential in patients with cancer: a systematic literature review. Br J Cancer 111: 866-73.

4. Gupta K, Kshirsagar S, Chang L, Schwartz R, Law PY, et al. (2002) Morphine stimulates angiogenesis by activating proangiogenic and survival-promoting signaling and promotes breast tumor growth. Cancer Res 62: 4491-8.

5. Singleton PA, Lingen MW, Fekete MJ, Garcia JG, Moss J (2006) Methylnaltrexone inhibits opiate and VEGF-induced angiogenesis: role of receptor transactivation. Microvasc Res 72: 3-11.

6. Farooqui M, Li Y, Rogers T, Poonawala T, Griffin RJ, et al. (2007) COX-2 inhibitor celecoxib prevents chronic morphine-induced promotion of angiogenesis, tumour growth, metastasis and mortality, without compromising analgesia. Br J Cancer 97: 1523-31.
7. Nguyen J, Luk K, Vang D, Soto W, Vincent L, et al. (2014) Morphine stimulates cancer progression and mast cells activation and impairs survival in transgenic mice with breast cancer. Br J Anaesth 113: i4-i13.

8. Chen C, Farooqui M, Gupta K (2006) Morphine stimulates vascular endothelial growth factor-like signaling in mouse retinal endothelial cells. Curr Neurovasc Res 3: 171-180.

9. Rittner HL, Roewer N, Brack A (2010) The clinical (ir)relevance of opioid-induced immune suppression. Curr Opin Anaesthesiol 23: 588-92.

10. Tegeder I, Grosch S, Schmidtko A, Haussler A, Schmidt H, et al. (2003) G protein-independent G1 cell cycle block and apoptosis with morphine in adenocarcinoma cells: involvement of p53 phosphorylation. Cancer Res 63: $1846-52$.

11. Mathew B, Lennon FE, Siegler J, Mirzapoiazova T, Mambetsariev N, et al. (2011) The novel role of the mu opioid receptor in lung cancer progression: a laboratory investigation. Anesth Analg 112: 558-67.

12. Kim JY, Ahn HJ, Kim JK, Kim J, Lee SH, et al. (2016) Morphine Suppresses Lung Cancer Cell Proliferation Through the Interaction with Opioid GrowthFactor Receptor: An In Vitro and Human Lung Tissue Study. Anesth Analg 123: 1429-36.

13. Khabbazi S, Nassar ZD, Goumon Y, Parat MO (2016) Morphine decreases the pro-angiogenic interaction between breast cancer cells and macrophages in vitro. Sci Rep 6: 31572.

14. Karaman H, Tufek A, Karaman E, Tokgoz O (2017) Opioids Inhibit Angiogenesis in a Chorioallantoic Membrane Model. Pain Physician 20: SE11-SE21.

15. Xia M, Tong JH, Ji NN, Duan ML, Tan YH, et al. (2016) Tramadol regulates proliferation, migration and invasion via PTEN/PI3K/AKT signaling in lung adenocarcinoma cells. Eur Rev Med Pharmacol Sci 20: 2573-80.

16. Mao L, Lin S, Lin J (2013) The effects of anesthetics on tumor progression. Int J Physiol Pathophysiol Pharmacol 5: 1-10.

17. Odunayo A, Dodam JR, Kerl ME, DeClue AE (2010) Immunomodulatory effects of opioids. J Vet Emerg Crit Care 20: 376-85.

18. Fodale V, D'Arrigo MG, Triolo S, Mondello S, La Torre D (2014) Anesthetic techniques and cancer recurrence after surgery. Scientific World J 2014: 328513.

19. Afsharimani B, Doornebal CW, Cabot PJ, Hollmann MW, Parat MO (2015) Comparison and analysis of the animal models used to study the effect of morphine on tumour growth and metastasis. Br J Pharmacol 172: 251-9.

20. Martins GR, Gelaleti GB, Moschetta MG, Maschio-Signorini LB, Zuccari DA (2016) Proinflammatory and anti-inflammatory cytokines mediated by NF- $\kappa$ B Factor as prognostic markers in mammary tumors. Mediators Inflamm 2016: 9512743.

21. Do Thi VA, Park SM, Lee H, Kim YS (2016) The Membrane-Bound Form of IL-17A Promotes the Growth and Tumorigenicity of Colon Cancer Cells. Version 2. Mol Cells 39: 536-42.

22. Wang H, Zhang Q, Kong H, Zeng Y, Hao M, et al. (2014) Monocyte chemotactic protein-1 expression as a prognosic biomarker in patients with solid tumor: a meta analysis. Int J Clin Exp Pathol 7: 3876-86.

23. Grivennikov S, Karin M (2011) Inflammatory cytokines in cancer: tumour necrosis factor and interleukin 6 take the stage. Ann Rheum Dis 70: i104-108.

24. Jonasch E, Haluska FG (2001) Interferon in oncological practice: review of interferon biology, clinical applications, and toxicities. Oncologist 6: 34-55.

25. Van Horssen R, Ten Hagen TL, Eggermont AM (2006) TNF-alpha in cancer treatment: molecular insights, antitumor effects, and clinical utility. Oncologist 11: 397-408.

26. Furusawa E, Hirazumi A, Story S, Jensen J (2003) Antitumour potential of a polysaccharide-rich substance from the fruit juice of Morinda citrifolia (Noni) on sarcoma 180 ascites tumour in mice. Phytother Res 17: 1158-64. 
Citation: Santana Huang AP, Rey Moura EC, Cunha Leal PD, Bogéa Serra ICP, Fernandes do Nascimento FR, et al. (2018) Evaluation of Morphine Effect on Tumor Growth in Mice. Clin Exp Pharmacol 8: 249. doi:10.4172/2161-1459.1000249

Page 5 of 5

27. Green DS, Nunes AT, Annunziata CM, Zoon KC (2016) Monocyte and interferon based therapy for the treatment of ovarian cancer. Cytokine Growth Factor Rev 29: 109-115.

28. Vahora H, Khan MA, Alalami U, Hussain A (2016) The Potential Role of Nitric Oxide in Halting Cancer Progression Through Chemoprevention. J Cancer Prev 21: 1-12.

29. Weinberg JB, Lopansri BK, Mwaikambo E, Granger DL (2008) Arginine, nitric oxide, carbon monoxide, and endothelial function in severe malaria. Curr Opin Infect Dis 21: 468-475.
30. Huang P, Feng L, Oldham EA, Keating MJ, Plunkett W (2000) Superoxide dismutase as a target for the selective killing of cancer cells. Nature 407: 390-5.

31. Vesely MD, Kershaw MH, Schreiber, RD, Smyth MJ (2011) Natural innate and adaptive immunity to cancer. Ann Rev Immunol 29: 235-271. 